\title{
Review
}

\section{Non-canonical kinase signaling by the death ligand TRAIL in cancer cells: discord in the death receptor family}

\author{
K Azijli ${ }^{1,2}$, B Weyhenmeyer ${ }^{1}$, GJ Peters ${ }^{2}$, S de Jong ${ }^{1}$ and FAE Kruyt ${ }^{\star, 1}$
}

Tumor necrosis factor-related apoptosis-inducing ligand (TRAIL)-based therapy is currently evaluated in clinical studies as a tumor cell selective pro-apoptotic approach. However, besides activating canonical caspase-dependent apoptosis by binding to TRAIL-specific death receptors, the TRAIL ligand can activate non-canonical cell survival or proliferation pathways in resistant tumor cells through the same death receptors, which is counterproductive for therapy. Even more, recent studies indicate metastases-promoting activity of TRAIL. In this review, the remarkable dichotomy in TRAIL signaling is highlighted. An overview of the currently known mechanisms involved in non-canonical TRAIL signaling and the subsequent activation of various kinases is provided. These kinases include RIP1, I $\mathrm{B} / \mathrm{NF}-\kappa \mathrm{B}$, MAPK p38, JNK, ERK1/2, MAP3K TAK1, PKC, PI3K/Akt and Src. The functional consequences of their activation, often being stimulation of tumor cell survival and in some cases enhancement of their invasive behavior, are discussed. Interestingly, the non-canonical responses triggered by TRAIL in resistant tumor cells resemble that of TRAIL-induced signals in non-transformed cells. Better knowledge of the mechanism underlying the dichotomy in TRAIL receptor signaling may provide markers for selecting patients who will likely benefit from TRAIL-based therapy and could provide a rationalized basis for combination therapies with TRAIL death receptor-targeting drugs.

Cell Death and Differentiation (2013) 20, 858-868; doi:10.1038/cdd.2013.28; published online 12 April 2013

Facts

- Tumor necrosis factor-related apoptosis-inducing ligand (TRAIL) receptors are attractive targets for anticancer therapy due to their selective ability to mediate caspasedependent apoptosis in tumor cells upon ligand binding without harming healthy tissues.

- Different TRAIL receptor-targeted agents have been developed showing promising antitumor activity in preclinical models, and several receptor agonists are being evaluated for activity in clinical studies.

- Resistance to the apoptosis-inducing effect of TRAIL receptor agonists is frequently encountered in tumor cells and can often be bypassed by combined treatments with radiotherapy and/or chemotherapy.

- Contrasting its apoptotic activity, in TRAIL-resistant tumor cells as well as in normal non-transformed tissue cells,
TRAIL can activate non-apoptotic (non-canonical) signals, resulting in the activation of various kinases that can enhance the proliferation, survival, migration/ invasion and angiogenic properties in a cell type-dependent manner.

\section{Open Questions}

- What is/are the molecular mechanism(s) underlying the dichotomy in TRAIL signaling in sensitive versus resistant tumor cells?

- What is the molecular basis of the apparent differences between TRAIL-R1- and TRAIL-R2-dependent signaling?

- Which factors produced by the tumor microenvironment determine the outcome of TRAIL signaling and through what mechanism(s)?

\footnotetext{
${ }^{1}$ Department of Medical Oncology, University of Groningen, University Medical Center Groningen, Groningen, The Netherlands and ${ }^{2}$ Department of Medical Oncology, VU University Medical Center, Amsterdam, The Netherlands

*Corresponding author: FAE Kruyt, Department of Medical Oncology, University of Groningen, University Medical Center Groningen, Hanzeplein 1, 9713 GZ, Groningen, The Netherlands. Tel: + 3150 3615531; Fax: + 3150 3614862; E-mail: f.a.e.kruyt@umcg.nl

Keywords: TRAIL; non-apoptotic; kinases; metastasis; RIP1

Abbreviations: ADAM, a disintegrin and metalloproteinase; c-Cbl, Casitas B-lineage lymphoma; CFLIP, cellular flice-like inhibitory protein; DISC, death-inducing signaling complex; ECs, endothelial cells; EGF, epidermal growth factor; EGFR, EGF receptor; ERK, extracellular regulated kinases; FADD, Fas-associated protein with death domain; HER, human epidermal receptor; IGF1R, insulin-like growth factor type 1 receptor; JNK, Jun $\mathrm{NH}_{2}$ terminal kinases; MAPK, Mitogen-activated protein kinases; MMP, Matrix metalloproteinase; Mst1, mammalian sterile 20-like kinase 1; mTOR, mammalian target of rapamycin; NEMO, NF- $\kappa$ B essential modulator; NF- $\kappa$ B, Nuclear factor kappa-light-chain-enhancer of activated B cells; NSCLC, non-small cell lung cancer; OPG, osteoprotegerin; PI3K, Phosphatidylinositide 3-kinases; PIP3, phosphatidylinositol $(3,4,5)$-triphosphate; PKC, protein kinase C; PMA, phorbol 12-myristate 13-acetate; PTEN, phosphatase and tensin homolog deleted on chromosome ten; RIP1, receptor-interacting protein kinase 1; RIP3, receptor-interacting protein kinase 3; ROCK, Rho kinase; ROS, reactive oxygen species; SEK1, stress-activated protein/ERK kinase 1; SFK, Src family kinases; SMAC, second mitochondria-derived activator of caspase; Src, Rous sarcoma oncogene cellular homolog; TAK1, transforming growth factor- $\beta$ (TGF- $\beta$ )-activated kinase 1 ; TGF- $\beta$, transforming growth factor- $\beta$; TRADD, TNF-receptor-associated death domain protein; TRAF2, TNF receptor-associated factor 2; TRAIL, Tumor necrosis factor-related apoptosis-inducing ligand; uPA, urokinase-type plasminogen activator; VSMCs, vascular smooth muscle cells; XIAP, X-linked inhibitor of apoptosis protein.

Received 8.1.13; revised 6.3.13; accepted 7.3.13; Edited by RA Knight; published online 12.4.13
} 
- Can possible identified mechanism(s)/proteins that function as an apoptotic switch in the TRAIL pathway be used as a target for developing therapeutic strategies for sensitizing tumor cells?

- Can TRAIL apoptosis sensitivity in tumor cells be predicted by not yet identified biomarkers, allowing the preselection of patients eligible for TRAIL receptor agonistic therapy?

The death ligand TRAIL induces apoptosis in a wide variety of tumors without harming normal cells. ${ }^{1-3}$ Moreover, its killing effect is irrespective of the proliferation status or tumor suppressor p53 status of cancer cells. These properties make TRAIL receptor-targeted therapy a very attractive anticancer approach.

The mechanisms by which TRAIL induces programmed cell death or apoptosis in cancer have been intensively investigated. TRAIL activates apoptosis via two membrane receptors, designated TRAIL-R1 (DR4) and TRAIL-R2 (DR5), whereas TRAIL-R3 (DcR1), TRAIL-R4 (DcR2) and circulating osteoprotegerin (OPG) have been proposed to function as decoy receptors that sequester TRAIL, causing the suppression of apoptosis. ${ }^{4,5}$ However, TRAIL-R4 was found to be corecruited with TRAIL-R2 to the death-inducing signaling complex (DISC) were it prevented initiation of caspase activation, which can be considered as an alternative regulatory mechanism of TRAIL signaling by these receptors. ${ }^{6}$ Overall, the more precise role and function of these decoy receptors in TRAIL resistance is currently not fully understood. A number of TRAIL receptor-targeting agents have been developed, including preparations of recombinant human soluble TRAIL (rhTRAIL) and derived variants, and agonistic monoclonal antibodies selective for either TRAIL-R1 or TRAIL-R2. ${ }^{1,7-10}$ High affinity and selective binding of either TRAIL-R1 or TRAIL-R2 by these receptor-selective agents together with reduced binding to decoy receptors is expected to enhance antitumor activity. However, currently it is unclear whether it will be more beneficial to target either TRAIL-R1 or TRAIL-R2 for optimal treatment, which may also vary in a tumor cell-specific way. For example, TRAIL signals its cell death function through TRAIL-R1 in pancreatic cancer cells ${ }^{11}$ and chronic lymphocytic leukemia, ${ }^{12}$ whereas in glioblastoma, ${ }^{13}$ colon and breast cancer cell lines, ${ }^{14}$ apoptosis induced by TRAIL goes via TRAIL-R2.

TRAIL apoptotic signaling is initiated following ligand binding to TRAIL receptors and subsequent recruitment of the adapter protein Fas-associated protein with death domain (FADD) and the cystein-aspartic protease procaspase-8, leading to the formation of a complex named the DISC, which promotes caspase-8 activation and further downstream caspase-3 activity, ultimately leading to cell death ${ }^{1,4,5,15}$ (see Figure 1). Cellular flice-like inhibitory protein (cFLIP), a non-functional procaspase-8 homolog, can compete with procaspase-8 for FADD binding leading to apoptosis suppression. Full activation of this so-called extrinsic apoptosis pathway often requires the cross-activation of intrinsic or mitochondrial apoptosis that is mediated by caspase-8dependent cleavage of pro-apoptotic $\mathrm{Bcl}-2$ family member Bid and subsequent mitochondrial disruption. ${ }^{16}$ Cells in which TRAIL-induced apoptosis depends on activation of the mitochondrial pathway have been named type II cells, contrasting type I cells where caspase- 8 activation is sufficient to directly activate effector caspases and apoptosis. ${ }^{16}$ The inhibitor of apoptosis protein (IAPs) family comprises proteins that can bind and inactivate caspases. For example, $X$-linked IAP (XIAP) inhibits caspases-3 and -9 , and its anti-apoptotic activity is neutralized by the release of second mitochondriaderived activator of caspase (SMAC) from mitochondria. ${ }^{17}$ More recently, death receptors have been discovered to trigger another way to die, named necroptosis. This caspaseindependent form of regulated necrotic cell death has been mostly studied in TNF receptor signaling, and appears important for the regulation of immunity and inflammation. ${ }^{18}$ TNF-induced necroptosis depends on the activation of receptor-interacting protein 1 (RIP1; also known as RIPK1), and RIP3 (also known as RIPK3), in a complex consisting of TRADD (TNF-receptor-associated death domain protein), FADD and caspase-8. Recently, TRAIL was found to activate necroptosis in tumor cells under acidic extracellular $\mathrm{pH}$ conditions, involving RIP1 and RIP3. ${ }^{19}$ Whether TRAIL can also induce the formation of a similar, so-called 'necroptosome' complex, consisting of, among others, RIP1/RIP3, remains to be shown.

In preclinical studies, approximately half of the tumor cells show resistance towards TRAIL-induced apoptosis, but combined treatment with various standard or experimental agents can re-sensitize these cells (reviewed ${ }^{20,21}$ ). Intrinsic TRAIL resistance in tumor cells involves blockades at different levels in the pathway, such as high levels of decoy receptors, limitations in DISC formation due to cFLIP-mediated inhibition, post-translational modifications of DISC proteins and high expression of anti-apoptotic $\mathrm{Bcl}-2$ proteins that inhibit mitochondrial apoptosis. Combined therapy with standard chemo- and radiotherapy as well as a number of targeted agents can overcome these apoptotic blockades. Commonly, these agents act by upregulation of TRAIL receptors and downregulation of anti-apoptotic proteins, resulting in enhanced DISC formation and mitochondria-dependent apoptosis. ${ }^{21,22}$

The promising antitumor activity in preclinical models has spurred early clinical studies with TRAIL receptor agonists in various tumor types. ${ }^{23-26}$ However, as described below, recent preclinical findings indicate pro-survival, proliferation and even metastatic activity of TRAIL, suggesting more caution when applying these TRAIL receptor agonists, particularly as single agents. In this review, we will give an update on the non-canonical (non-apoptotic) signaling activity of the TRAIL pathway in tumor and non-transformed cells. The different kinase cascades involved are described and the consequences for TRAIL-based therapy are discussed.

\section{TRAIL Receptor Signaling Complexes and Kinase Activation}

The early molecular events leading to non-canonical TRAIL signaling are complex and not well-understood. Co-immunoprecipitation experiments have indicated the formation of a so-called secondary signaling complex subsequent to the assembly of the primary DISC. ${ }^{27}$ This secondary complex was found to contain RIP1, TNF receptor-associated factor 2 


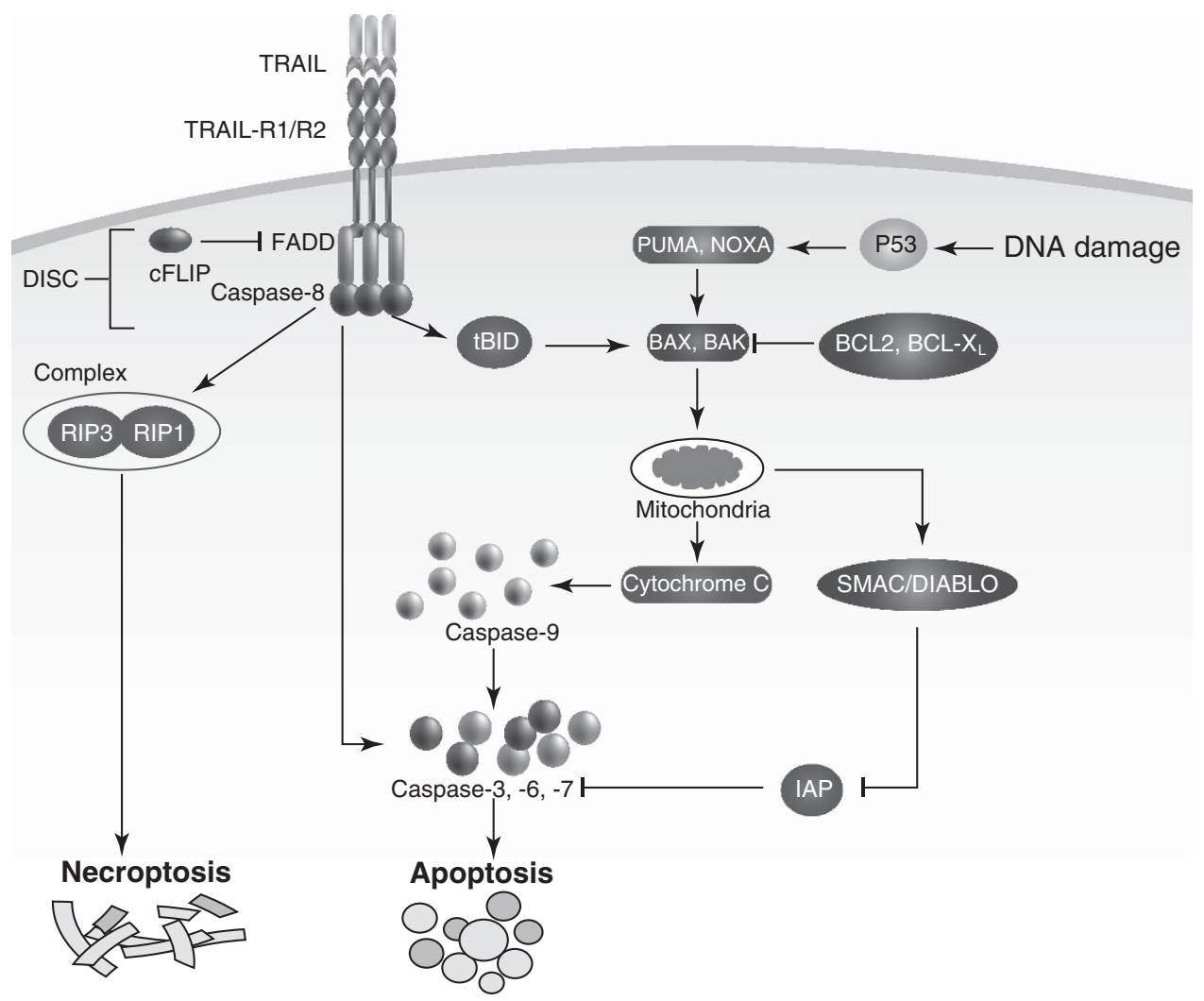

Figure 1 The TRAIL apoptotic pathway. Simplified and schematic representation of the pathway. Binding of TRAIL or generated agonistic agents to the TRAIL receptors results in the recruitment of FADD and procaspase-8, also known as the DISC. Subsequently, caspase- 8 cleavage in the DISC can activate downstream caspase-3, leading to the induction of apoptosis (extrinsic pathway). The caspase-8 analog cFLIP can compete for FADD binding and inhibit DISC formation. Caspase-8 can also cleave the Bcl-2 family member Bid into tBid engaging the intrinsic pathway by binding to Bax, causing mitochondrial membrane permeabilization and the release of apoptogenic factors such as cytochrome $c$. Pro-survival Bcl-2 family members can prevent mitochondrial permeabilization. IAPs, such as XIAP, can bind to caspases and inhibit apoptosis. Necroptosis, a regulated form of caspase-independent necrotic cell death, can also be activated through TRAIL receptors under specific conditions. This involves the activation of RIP1 and RIP3 in a complex that has not been precisely clarified as yet. See text for more details

(TRAF2) and NF- $\kappa \mathrm{B}$ (nuclear factor kappa-light-chain-enhancer of activated $B$ cells) essential modulator (NEMO)/IKK $\gamma$, in addition to FADD and active caspase-8. In this context, the localization of the TRAIL receptors in the cell membrane also appears to have a role in complex formation. In particular, TRAIL receptor localization in lipid rafts enables apoptosis activation. ${ }^{28}$ Lipid rafts are plasma membrane domains enriched in cholesterol and glycolsphingolipids, and function as signaling platforms that serve colocalization of requisite components. In the same study, TRAIL receptors' complex assembly outside the rafts was associated with non-canonical signaling, mediated by RIP1 and CFLIP. ${ }^{28}$ Aggregation of the TRAIL-R1 and -R2 in lipid rafts also occurred only in TRAILsensitive non-small lung cancer (NSCLC) H460 cells and not in the resistant A549 cells. ${ }^{29}$ Whether lipid raft localization of TRAIL receptors is a consequence or a cause of DISC formation remains to be proven.

Additional layers of regulation are provided by the expression of DISC inhibitors, such as CFLIP, and the phosphorylation and/or ubiquitination of several TRAIL receptor-interacting proteins, including caspase-8 and RIP1, which has been more extensively reviewed elsewhere. ${ }^{15,30,31}$ Regardless of the more precise composition and regulation of the complexes involved, non-canonical TRAIL receptor-induced kinase activation has been reported in various cell- and tumor types. These cascades were demonstrated to result in pro-inflammatory, proliferative, survival and migratory responses, and are in more detail discussed below.

\section{$\mid \kappa B / N F-\kappa B$ Survival Signaling}

Activation of the inflammatory and cell survival pathways controlled by the transcription factor $\mathrm{NF}-\kappa \mathrm{B}$ was one of the first reported non-canonical signals elicited by TRAIL (see Figure 2 and Table 1). Both TRAIL-R1 and -R2 were found to activate NF- $\kappa$ B in a TRADD- and RIP1-dependent way. ${ }^{32-34}$ NEMO $(\mathrm{IKK}-\gamma)$ was found to be part of the secondary complex, able to recruit $\mathrm{IKK} \alpha / \beta$ to the signaling complex causing the phosphorylation and subsequent proteasomal degradation of the inhibitor of $\mathrm{k} \beta\left(\mathrm{I}_{\kappa} \mathrm{B}\right)$, leading to release and accumulation of $\mathrm{NF}-\kappa \mathrm{B} .{ }^{27} \mathrm{NF}-\kappa \mathrm{B}$ then translocates to the nucleus where it can activate the transcription of, among others, the anti-apoptotic genes $c F L I P, B c /-x_{L}, M c l-1$ and clAPs. ${ }^{35-38}$ In preclinical tumor models such as (primary) leukemia, ${ }^{39}$ neuroblastoma, ${ }^{40}$ pancreatic cancer, ${ }^{41}$ mantle cell lymphoma cells ${ }^{42}$ and NSCLC, ${ }^{43}$ inhibition by overexpression of an $\mathrm{l} \kappa \mathrm{B}$ dominant-negative version or by selective chemical inhibitors enhanced TRAIL apoptosis. 


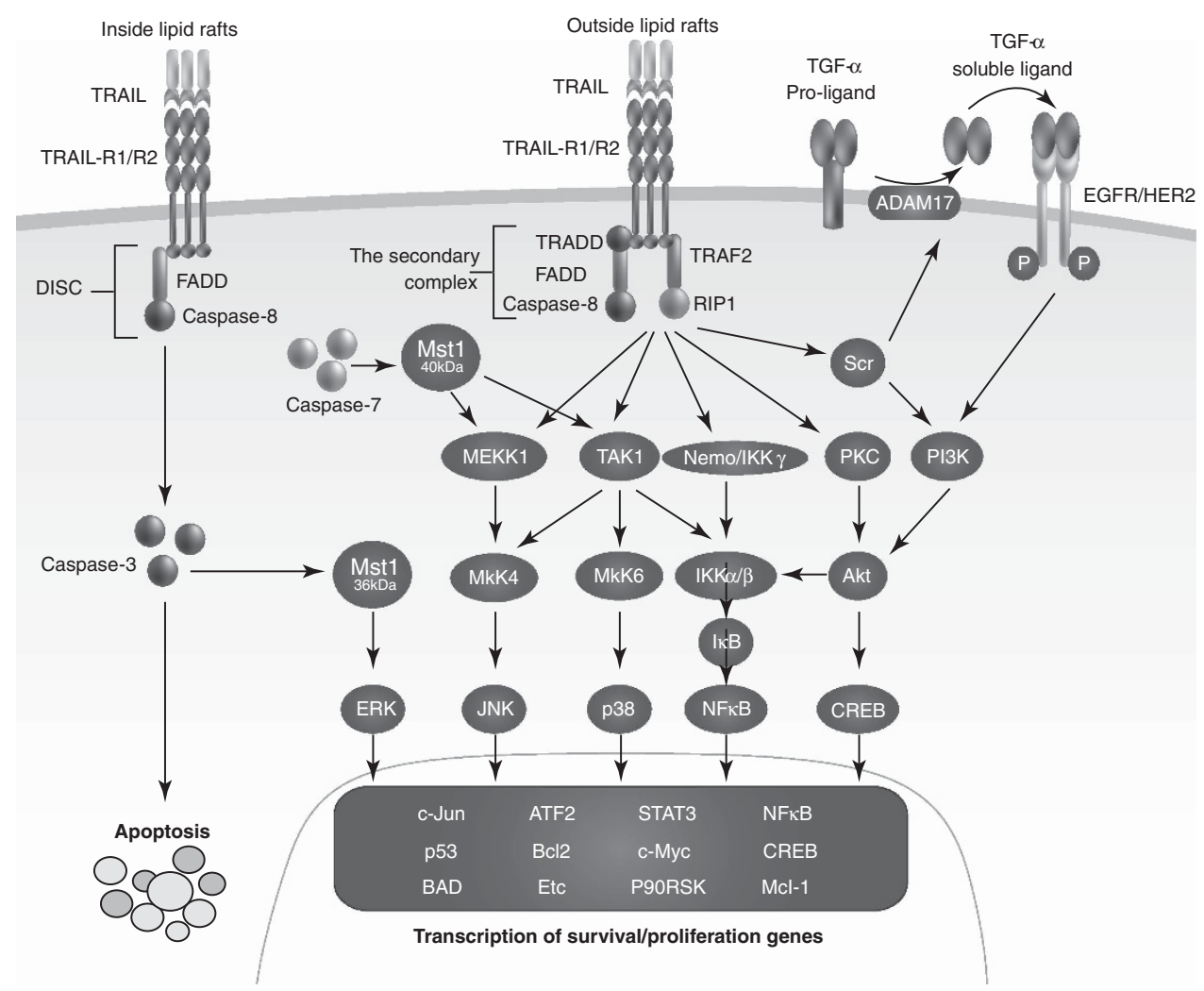

Figure 2 Canonical and non-canonical TRAIL signaling in cancer cells. Schematic overview of apoptotic and proliferation/pro-survival signals elicited by the activation of TRAIL receptors. Following binding of TRAIL receptor agonists to their death receptors, the DISC can be formed, resulting in apoptosis. A secondary complex can also be formed after TRAIL receptor activation, leading to the activation of various kinases and the induction of direct or indirect non-apoptotic responses as indicated. The more precise molecular events required for secondary complex formation are subject of investigations. The complex could be associated with TRAIL receptors at the membrane or formed in the cytoplasm. See text for more details

Interestingly, NF- $\kappa \mathrm{B}$ can have dual activity, as it was found to mediate the upregulation of TRAIL receptors on one hand, and enhance $\mathrm{Bcl}-\mathrm{x}_{\mathrm{L}}$ expression and apoptosis resistance on the other. ${ }^{38}$ More recently, a pro-apoptotic role for NF- $\kappa \mathrm{B}$ was demonstrated in glioma cell lines, where inhibition of the NF$\kappa \mathrm{B}$ pathway reduced TRAIL-induced apoptosis via an as yet elusive mechanism. ${ }^{44}$

\section{Mitogen-Activated Protein Kinases (MAPKs) in TRAIL Signaling}

MAPKs are enzymes that control important physiological processes, such as gene expression, motility, metabolism, mitosis and programmed cell death. In mammals, six distinct groups of MAPKs have been characterized, extracellular regulated kinases (ERK1/2), Jun $\mathrm{NH} 2$ terminal kinases (JNK1/2/3), p38 (p38 $\alpha / \beta / \gamma / \delta), E R K 7 / 8, E R K 3 / 4$ and ERK5. ${ }^{45}$ TRAIL can activate c-Jun N-terminal kinase (JNK), p38 and ERK1/2 in several cancer cell lines with dual effects, but mostly contributing to cell proliferation and pro-survival signaling, as outlined further below.

c-Jun N-terminal kinases. The JNKs are stress-activated members of the MAP kinase family that can be activated by TRAIL via both caspase-dependent and -independent mechanisms in a cell type-specific way. ${ }^{46}$ FADD appeared to be dispensable for JNK activation. In lymphoid cells, JNK pathway activation by TRAIL contributed to apoptosis activation. ${ }^{47}$ JNK activation involved a TRAF2-MEKK1MKK4-dependent signaling pathway in human embryonic kidney 293 cells $^{48}$ and required RIP1 in prostate cancer cells. $^{49}$ Both TRAF2 and RIP1 were detected in the secondary complex and were required for JNK activation in fibrosarcoma cells. ${ }^{27}$ JNK activation results in phosphorylation of its well-known target, the transcription factor c-Jun/ AP1, but can also directly phosphorylate the proapoptotic Bcl-2 family member Bim in hepatocytes, thereby stabilizing the protein and facilitating mitochondrial apoptosis. ${ }^{50}$ A role for JNK and Bim has also been found in the activation of a lysosmal death pathway induced by TRAIL in cholangiocarcinoma cells. ${ }^{51}$ Another cell death route was also connected to TRAIL receptor-dependent activation of JNK; JNK appeared to phosphorylate a key autophagy regulator, Beclin-1, leading to autophagic cell death in HCT116 cells. $^{52}$ Synergistic apoptosis activation by chemotherapy and TRAIL receptor agonists was shown to involve MKK4-dependent JNK activation. Mitogen-activated protein kinase (MAPK) p38 was also activated and suppression of the activation of these kinases by the antioxidant $\mathrm{N}$-acetyl cysteine prevented synergistic effects. ${ }^{53}$ However, in contrast, direct inhibition of JNK by RNA interference or chemical inhibition augmented TRAIL-induced apoptosis in 
Table 1 Summary of the kinases activated by TRAIL in different tumor types

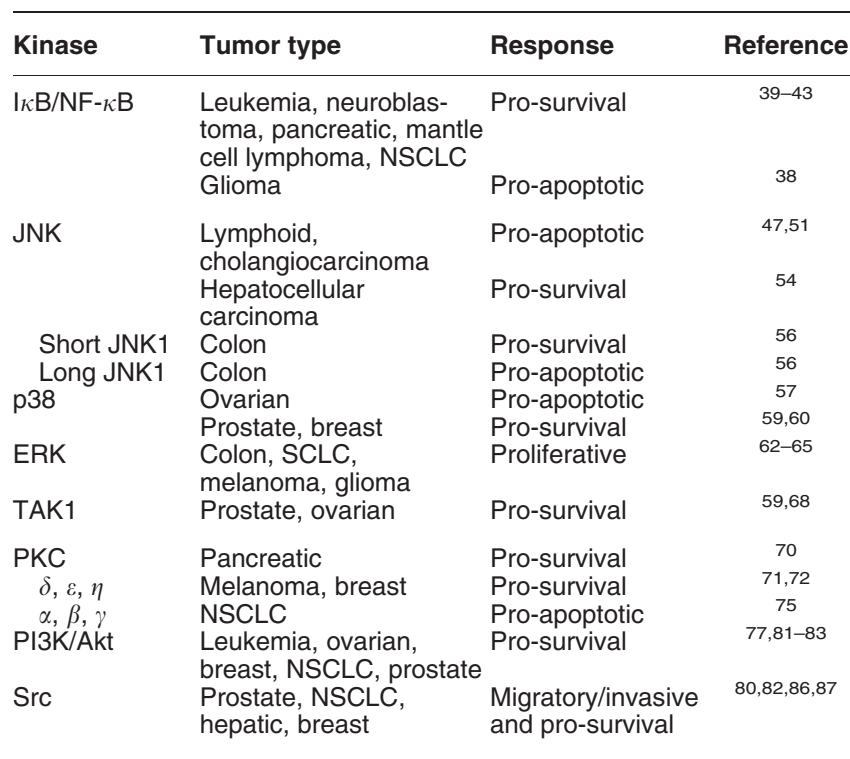

Abbreviations: ERK, extracellular regulated kinases; $\mathrm{I}_{\kappa} \mathrm{B}$, inhibitor of $\mathrm{k} \beta$; JNK, C-Jun $\mathrm{NH}_{2}$ terminal kinases; NF- $\kappa \mathrm{B}$, nuclear factor kappa-light-chain-enhancer of activated B cells; NSCLC, non-small cell lung cancer; PI3K, Phosphatidylinositide 3-kinases; PKC, protein kinase; SCLC, small cell lung cancer; Src, Rous sarcoma oncogene cellular homolog; TAK1, transforming growth factor- $\beta$ (TGF- $\beta$ )-activated kinase 1

The functional consequences of activation being either pro-apoptotic, prosurvival, proliferative or migratory are indicated.

hepatocellular carcinoma cells. ${ }^{54}$ This indicates that JNK can have opposite effects in TRAIL signaling that may be dependent on the cellular context. These dual functions can in part be due to the duration or magnitude of the activation of the pathway. For example, it was found that prolonged activation of JNK by TNF induces apoptosis, whereas transient activation of JNK promotes cell survival. ${ }^{55}$ Furthermore, a recent study has shown that in colon cancer cell lines, the short JNK1 isoforms (JNK1 11 and JNK1 $\beta 1$ ) transmit an anti-apoptotic signal, whereas the long isoforms (JNK1 $\alpha 2$ and JNK1 $\beta 2$ ) are pro-apoptotic upon activation of TRAIL. ${ }^{56}$ This may also provide an explanation for the dual role of JNK.

P38 MAPK. Several reports have shown that TRAIL can activate p38 MAPK. P38 activation can occur through the formation of the secondary complex consisting of FADD, caspase-8, RIP1 and TRAF2. ${ }^{27}$ Lee et al. ${ }^{57}$ found TRAILinduced p38 activation in HeLa cells to be responsible for caspase activation and apoptosis. Elevation of reactive oxygen species (ROS) by TRAIL appeared instrumental for p38 activation. P38 activation by TRAIL was also observed in DLD1 colon cancer cells, however, in these cells inhibition of p38 did not affect TRAIL-mediated cell death. ${ }^{58}$ In yet other tumor cells, p38 was found to suppress apoptosis. In prostate cancer cells, TRAIL induced p38 phosphorylation causing the transcriptional upregulation of anti-apoptotic Bcl-2 family member $\mathrm{Mcl}-1$, thus rescuing the prostate cancer cells from apoptosis. Inhibition of p38 with chemical inhibitor, SB203580, increased the level of cell death by TRAIL in these cells. ${ }^{59}$ Breast carcinoma cells could also be sensitized for TRAIL after inhibition of p38, indicating that this kinase contributes to cell survival in these cells. ${ }^{60}$ Thus, p38 can either suppress or enhance the apoptotic effect of TRAIL in a cell type-specific way.

ERKs. The activation of ERKs by TRAIL has also been reported in a number of reports. In neuroblastoma cells, TRAIL-induced ERK1/2 phosphorylation ${ }^{61}$ and the inhibition of ERK1/2 could enhance TRAIL-dependent death in colon cancer cells. ${ }^{62}$ Even more, in small cell lung cancer (SCLC) cells lacking caspase-8, TRAIL caused cell proliferation in some but not all SCLC cell lines tested and was mediated by TRAIL-R2. ${ }^{63}$ TRAIL-induced proliferation could be prevented by chemical inhibition or siRNA-mediated knockdown of ERK1/2, identifying this pathway as a critical proliferation mediator. ${ }^{63}$ Also in a panel of human melanoma cell lines with variable sensitivities for TRAIL, ERK1/2 phosphorylation was detected within $30 \mathrm{~min}$ of TRAIL treatment. ${ }^{64}$ ERK1/2 inhibition resulted in downregulation of $\mathrm{Bcl}-2, \mathrm{Bcl}-\mathrm{X}_{\mathrm{L}}$ and Mcl-1 expression, providing an explanation for enhanced TRAIL-induced mitochondrial apoptosis in these cells. TRAIL-resistant human glioma cells also demonstrated enhanced cell proliferation upon TRAIL treatment that could be linked to ERK1/2 activation. ${ }^{65}$ ERK inhibition suppressed stimulation of proliferation but did not sensitize for TRAIL. Knockdown of cFLIP on the other hand prevented ERK activation and resulted in partial sensitization for TRAILdependent apoptosis. ${ }^{65}$ Thus, the activation of ERK by TRAIL generally has been implicated in stimulation of cell survival and proliferation of tumor cells.

As mentioned, the secondary complex and active caspase8 have been implicated in MAPK activation. ${ }^{27}$ However, an alternative caspase-8-requiring mechanism was reported by Song and Lee ${ }^{66}$ in DU-145 prostate cancer cells. They found that mammalian sterile 20-like kinase 1 (Mst1), a ubiquitously expressed serine/threonine kinase and caspase substrate, could activate p38 and JNK through a caspase-7 cleavagegenerated $40 \mathrm{kDa}$ form of Mst1. A caspase-3-generated $36 \mathrm{kDa}$ form of Mst1 could activate ERK. ${ }^{66}$ The same group reported MAP3K (MEKK1) and stress-activated protein/ERK kinase 1 (SEK1) to mediate TRAIL-induced JNK/p38 phosphorylation, also requiring active caspase- $8 .{ }^{67}$

TGF- $\beta$-activated kinase 1 (TAK1). TAK1 is a member of the MAP3K family and is activated by various cytokines, such as the TGF- $\beta$, TNF- $\alpha$, interleukin-1 (IL-1) and ligands of the Toll-like receptors. It is a key regulator of the NF- $\kappa$ B subunit p65/RelA and MAPK activity. TRAIL activated TAK1 in HeLa cells resulting in p65, JNK and p38 activation; siRNA knockdown or chemical inhibition of TAK1 enhanced TRAIL-induced apoptosis. ${ }^{68}$ The earlier mentioned activation of p38 by TRAIL in prostate cancer cells was preceded and dependent on activation of TAK1, leading to transcriptional upregulation of $\mathrm{Mcl}-1$ and suppression of apoptosis. ${ }^{59}$ Inhibition of TAK1 is an effective approach to increase TRAIL sensitivity as was reported by Morioka et al. ${ }^{69}$, although in their study, direct phosphorylation of TAK1 after TRAIL was not demonstrated. In fibroblasts and keratinocytes derived from $\mathrm{TAK}^{-1-}$ knockout mice, as well as in tumor cell lines Saos2 and HeLa cells with silenced TAK1 expression, sensitization to TRAIL killing was observed 
independent of NF- $\kappa \mathrm{B}$ activity. In the absence of TAK1, TRAIL exposure resulted in ROS accumulation and subsequent degradation of clAP, leading to caspase- 3 activation and apoptosis. Overall, TAK1 activation by TRAIL appears to be associated with apoptosis resistance through either affecting NF- $\kappa \mathrm{B}$ signaling and/or JNK, p38 activation.

\section{Dual Effects on Apoptosis by Protein Kinase C (PKC)}

A number of studies have reported on the TRAIL receptordependent activation of PKC and its isoforms. Activation of PKC by TRAIL in resistant pancreatic adenocarcinoma cells had anti-apoptotic effects, and PKC inhibition with Gö6983 sensitized for apoptosis. ${ }^{70}$ Furthermore, TRAIL-sensitive cells could be made resistant following PKC activation with phorbol 12-myristate 13-acetate (PMA). In apoptosis-sensitive melanoma cells, TRAIL stimulated the phosphorylation of PKC $\delta$ and $\mathrm{PKC} \varepsilon$, resulting in apoptosis-protecting effects. ${ }^{71}$ In the same study, activation of PKC by PMA suppressed apoptosis by preventing the translocation and activation of pro-apoptotic Bax to the mitochondria and subsequent apoptosis. Other studies also reported extracellular stimuli-dependent activation of $\mathrm{PKC}$, in particular of the isotypes $\mathrm{PKC} \varepsilon$ and $\mathrm{PKC} \eta$. For example, in breast cancer cells, PKC $\varepsilon$ caused TRAIL resistance by activating Akt, followed by Hdm2 phosphorylation. Hdm2, on its turn, reduced p53 expression, leading to the downregulation of Bid and suppression of mitochondrial pathway activation. ${ }^{72}$ Activation of PKC also inhibited the recruitment of FADD and caspase-8, resulting in disruption of DISC formation and a decrease in apoptosis. ${ }^{73}$

In contrast to the mentioned anti-apoptotic effects of TRAILand extracellular-induced PKC activation, the activation of conventional PKC isoforms $(\alpha, \beta, \gamma)$ by PMA or bryostatin-1 was reported to increase the expression of pro-apoptotic Bad and the TRAIL receptors, leading to sensitization for apoptosis by TRAIL. ${ }^{74}$ In NSCLC, PKC $\alpha$ and PKC $\beta$ increased TRAIL-R2 expression, and sensitized for TRAIL-induced apoptosis. $^{75}$ Thus, it appears that activation of $\mathrm{PKC} \delta, \mathrm{PKC} \varepsilon$ and $\mathrm{PKC} \eta$ leads to apoptosis inhibition, whereas activation of PKC isoforms $\alpha, \beta$ and $\gamma$ enhances apoptosis induced by TRAIL, which is cell type-dependent.

\section{Phosphatidylinositide 3-Kinases (PI3K)/Akt Signaling Counteracts Apoptosis}

Akt or protein kinase $B(P K B)$ is one of the most critical kinases in the regulation of cell survival. Enhanced activity of the PI3K/Akt pathway is found in many malignancies and is associated with the stimulation of cell growth and cell survival. ${ }^{76}$ In leukemic T Jurkat cells, TRAIL phosphorylated PI3K and Akt within $30 \mathrm{~min}$, and inhibition of PI3K with the pharmacological inhibitor LY294002 sensitized cells for TRAIL-induced apoptosis. ${ }^{77}$ Sensitization was associated with reduced nuclear translocation of $\mathrm{NF}-\kappa \mathrm{B}$ p65, reflecting an earlier-found direct ability of $\mathrm{PI} / \mathrm{K} / \mathrm{Akt}$ to phosphorylate and transactivate p65 and NF- $\kappa \mathrm{B}$ signaling upon TNF treatment. $^{78,79}$ However, NF- $\kappa$ B inhibition did not sensitize for TRAIL apoptosis but enhanced necrotic cell death. More recently, cross-talk between Akt and NF- $k B$ was found to involve direct phosphorylation of $\mathrm{IKK} \beta$ by $A \mathrm{kt}$, leading to nuclear translocation of NF- $\kappa \mathrm{B}$ and increased anti-apoptotic gene expression causing resistance for TRAIL. ${ }^{80}$

TRAIL-induced Akt phosphorylation has been reported in various other tumor cells. In TRAIL-resistant ovarian- and breast cancer cell lines, TRAIL exposure induced phosphorylation of Akt and its substrate, the serine/threonine kinase mTOR (mammalian target of rapamycin), within hours of treatment. ${ }^{81}$ The cells could be sensitized for TRAIL by adding the PI3K inhibitor LY294002 or by restoring the expression of the tumor suppressor gene PTEN (phosphatase and tensin homolog deleted on chromosome ten) in PTEN-negative tumor cells. PTEN inhibits the PI3K/Akt pathway by dephosphorylating phosphatidylinositol $(3,4,5)$-triphosphate (PIP3), a cofactor for Akt activation. Recently, also TRAIL-dependent phosphorylation of Akt was reported in TRAIL-resistant NSCLC cells, and inhibition of Akt resulted in sensitization for TRAIL apoptosis. ${ }^{82}$ Akt activation has also been described in TRAIL-sensitive prostate adenocarcinoma DU-145 cells. ${ }^{83}$ Akt inhibition enhanced apoptosis activation by TRAIL, and interestingly, roles for the Rous sarcoma oncogene cellular homolog (Src) and Casitas B-lineage Iymphoma (c-Cbl) kinases were found upstream of Akt in this signaling route. Based on work in the same prostate cancer cell line, Song et al. ${ }^{84}$ proposed TRAIL-induced Akt activation to be in part responsible for the development of acquired TRAIL resistance. In this model, Akt phosphorylates its substrate Bad, another $\mathrm{Bcl}-2$ family protein, leading to inactivation of the proapoptotic function of this $\mathrm{BH}$-only protein and suppression of mitochondrial apoptosis. Moreover, the same group identified another TRAIL-dependent route leading to Akt activation, involving a cascade of p38 and subsequent HSP27 phosphorylation that was required for catalytic Akt activation. ${ }^{67}$ An interesting but mechanistically poorly understood phenomenon is the recent finding that ectopic expression of TRAIL$\mathrm{R} 4 / \mathrm{DcR} 2$ in HeLa cells enhanced cell growth in vitro, and as xenograft transplants in mice in a ligand-independent way. ${ }^{85}$ In these cells, constitutive Akt activation was detected and inhibition of Akt suppressed tumor growth. Overall, the activation of the PI3K/Akt pathway by TRAIL has been demonstrated in several tumor models, showing that inhibition of this route sensitizes for apoptosis.

\section{Direct and Indirect Activation of Src Suppresses Apoptosis}

As mentioned earlier, in DU-145 prostate cancer cells, TRAIL-induced Akt activation was mediated by the nonreceptor tyrosine kinase Src and inhibition of Src sensitized cells for apoptosis. ${ }^{83}$ In line with this, the inhibition of Src could restore TRAIL sensitivity in resistant hepatic carcinoma cells by facilitating caspase- 8 cleavage. ${ }^{86}$ Interesting in this respect is the finding that survival of metastatic breast cancer cells in the bone of mice was dependent on Src. ${ }^{87}$ Intriguingly, Src activation amongst other pathways was associated with TRAIL resistance, allowing the survival of disseminated breast cancer cells in the bone marrow by rendering them resistant to TRAIL produced by the microenvironment. Mechanistically, Src has been directly linked with apoptosis resistance. The epidermal growth factor (EGF) was found to promote Src-mediated phosphorylation of caspase-8 at 
Tyrosine 380, thus impairing death receptor/caspase-8dependent apoptosis. ${ }^{88}$ Another link between TRAIL-induced Src activation and resistance to apoptosis has been identified, which involves the indirect activation of the EGF receptor (EGFR). ${ }^{89}$ TRAIL could stimulate signaling by human epidermal receptor (HER) family members, EGFR and HER2, in colorectal cancer cells by activating the Src family kinases (SFK), which in turn activates a disintegrin and metalloproteinase (ADAM) family member ADAM-17, leading to the shedding of TGF- $\alpha$. Subsequently, TGF- $\alpha$, a ligand of EGFR, activated the EGFR/HER2 pro-survival signaling in an autocrine and paracrine manner. ${ }^{89}$ Taken together, Src activation has been consistently associated with TRAIL signaling and apoptosis resistance.

\section{Mechanisms of TRAIL-Induced Migration and Invasion}

When considering the physiological function of TRAIL, which is thought to include innate immune surveillance against tumor development by suppressing tumor initiation and metastasis, ${ }^{90,91}$ the more recently found proinvasive effects of TRAIL on tumor cells were surprising (see also Figure 3). Ishimura et al. ${ }^{92}$ reported that TRAIL administration stimulates cell migration and invasion in apoptosis-resistant cholangiocarcinoma cells in a NF- $\kappa$ B-dependent manner. In another study, the administration of aggregated TRAIL enhanced primary tumor growth and also stimulated the formation of distant metastases in an orthotopic xeno-transplantation model of human pancreatic ductal adenocarcinoma cells overexpressing $\mathrm{Bcl}-\mathrm{x}_{\mathrm{L}}\left(\right.$ Colo357/Bcl- $\left.\mathrm{x}_{\mathrm{L}}\right) \cdot{ }^{93}$ In these cells, TRAIL stimulated the expression of proinflammatory cytokines, such as IL-8, urokinase-type plasminogen activator (UPA) and the matrix metalloproteinases (MMP)-7 and -9, which were linked to invasive behavior. ${ }^{93,94}$ In colon cancer HCT116 cells, ectopic expression of mutated PI3K catalytic subunit alpha (PIK3CA) blocked TRAILinduced apoptosis downstream of caspase-8 cleavage, leading to induction of proinflammation and cell invasion responses. ${ }^{95}$ The oncogenic proteins, K-RAS and Raf-1 were mentioned as critical factors in switching the pro-apoptotic function of death receptors into a proinvasive function in these colon cancer cells. Evidence was provided that these oncogenic kinases convert death receptors into invasioninducing receptors by suppressing the Rho kinase (ROCK)/ LIM kinase-mediated phosphorylation of the actin-severing protein cofilin, which is a regulator of actin dynamics during cell invasion. ${ }^{96}$ However, whether the suggested critical role of K-RAS and RAF-1 in switching the function of death receptors to invasive receptors is of more general relevance will need further confirmation in a broader panel of tumor cells. More recently, the RIP1/Src/STAT3 axis was identified to mediate TRAIL-dependent migration and invasion of TRAILresistant NSCLC cells. ${ }^{82}$ Using TRAIL receptor-selective TRAIL variants, TRAIL-R2 was found to be the main mediator of invasion. In this model, inhibition of Src as well as STAT3 prevented invasion but did not notably sensitize for TRAIL.

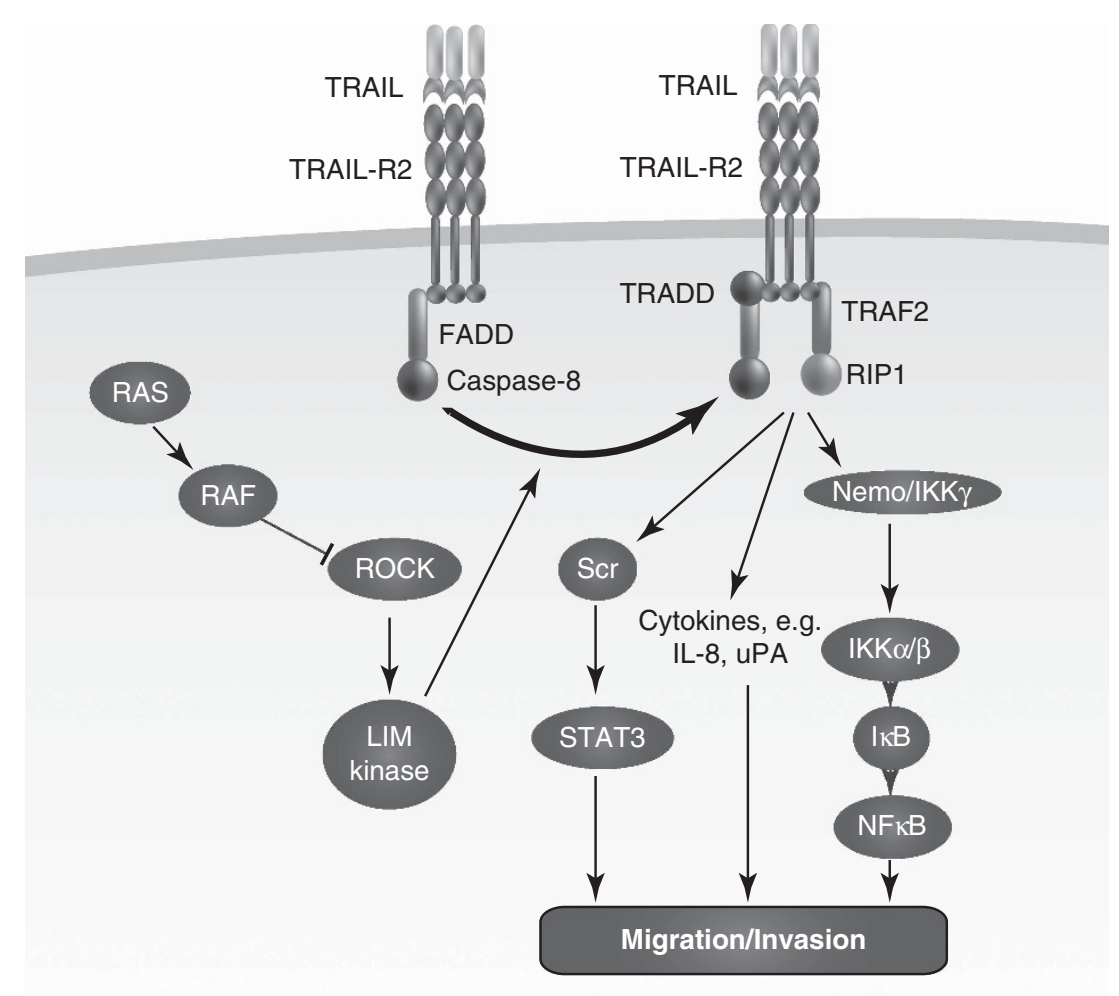

Figure 3 TRAIL-dependent routes that can induce migration and invasion of tumor cells. Schematic representations of the mechanism identified that mediate TRAIL-induced tumor cell invasion. The composition of the different protein complexes induced by TRAIL and the mechanisms controlling this remain to be further elucidated. See text for more details 
Overall, it appears that tumor cells have altered the antimetastatic activity of TRAIL into an invasion stimulatory signal, thus using this death pathway to their malignant benefit.

\section{Non-Apoptotic TRAIL Signaling in Non-Transformed Cells}

Non-canonical kinase activation by TRAIL is also known to occur in normal healthy tissue cells that are resistant to the killing effect of TRAIL receptor agonists. ${ }^{97}$ TRAIL-dependent pro-inflammatory, pro-survival, proliferation and cell migratory responses have been observed in different cell types. For example, TRAIL activated Akt-dependent survival and ERK1/ 2-dependent proliferation in human endothelial cells (ECs). ${ }^{98}$ In ECs, TRAIL was also reported to induce NF- $\kappa$ B signaling leading to enhanced expression of adhesion molecules. ${ }^{99}$ Furthermore, ECs exposed to TRAIL displayed enhanced migration and vessel tube formation ability suggestive of proangiogenic activity of TRAIL. ${ }^{100}$ However, a recent study by Wilson et al. ${ }^{101}$ showed that activation of murine TRAIL-R disrupts tumor - and not normal vasculature - in tumorbearing mice models, suggesting differences in TRAIL signaling networks between normal and tumor stromal ECs. In vascular smooth muscle cells (VSMCs), TRAIL stimulated the production of the pro-inflammatory cytokines TNF $\alpha, \mathrm{IL}-1 \beta$ and INF $\gamma$, leading to apoptosis protection and induction of proliferation and migration in an ERK1/2-dependent manner. ${ }^{102}$ In addition, several other mechanisms have been reported to contribute to these effects of TRAIL, such as activation of NF- $\kappa \mathrm{B}$, insulin-like growth factor type 1 receptor (IGF1R) and SP-1. ${ }^{103,104}$ Furthermore, TRAIL could stimulate p38-dependent INF $\gamma$ secretion and proliferation in T cells, ${ }^{105}$ enhance survival signaling in eosinophils of asthma patients, ${ }^{106}$ and stimulate ERK1/2 and Akt-dependent survival of fibroblast-like synoviocytes derived from rheumatoid arthritis patients. ${ }^{107}$

Interestingly, also a role for TRAIL signaling has been found in the differentiation of different cell types. In intestinal mucosa cells, TRAIL acted as a growth-arrest mediator via activation of cyclin-dependent kinases p21 and p27 thought to stabilize the differentiated phenotype. ${ }^{108}$ In human keratinocytes, TRAIL induced both caspase-dependent differentiation and apoptosis. ${ }^{109}$ Furthermore, TRAIL induced differentiation of macrophage lineage precursors into osteoclasts by stimulating pro-inflammatory cytokine production via NF- $\kappa \mathrm{B}$, ERK and p38 activation, independently of caspase cleavage. ${ }^{110}$ The molecular mechanisms causing the activation of these alternative TRAIL signaling routes in normal cells remain largely elusive. Some light on this was shed recently by the observation that in mouse embryonal fibroblasts derived from TAK1 and TRADD knockout mice, apoptosis sensitivity to TRAIL was detected. TRADD and TAK1 could be linked to the activation of NF- $\kappa \mathrm{B}$-dependent pro-survival signals, such as upregulation of cFLIP, thus causing resistance. ${ }^{111,112}$ Another study proposed that recruitment of TRADD to the TRAIL receptor reduces the levels of FADD in the complex while stimulating RIP1 interactions leading to pro-survival signals. ${ }^{113}$ Thus, it appears that similar non-canonical signals can be activated by TRAIL in non-transformed normal cells as in TRAIL-resistant tumor cells.

\section{CD95/FAS}

The above discussed activation of non-canonical signaling by TRAIL receptors is not unprecedented in the death receptor family. The well-studied death receptor CD95 (FAS/Apo1) and CD95 ligand (FAS ligand/Apo1 ligand) are not only known for their apoptosis-activating properties but also for their ability to activate non-apoptotic signaling cascades, leading to increased cell proliferation, survival, inflammation, differentiation, migration and invasion (reviewed $\mathrm{n}^{114}$ ). For example, CD95 induces apoptosis in the liver. However, in a damaged liver, it stimulates liver regeneration by enhancing proliferation of hepatocytes. ${ }^{115}$ CD95 can also stimulate MAPK activation in neural progenitor cells and was found to regulate neural branching in the developing mouse brain. ${ }^{116,117}$ Non-apoptotic signaling in apoptosis-resistant tumor cells has also been reported, including tumor-promoting activity in a lung cancer mouse model, ${ }^{118}$ and CD95L-dependent NF- $\kappa$ B and ERK1/2 activation leading to enhanced invasiveness in various tumor cell types. ${ }^{119}$ In glioblastoma, CD95-dependent tumor cell invasion was found to be mediated by the Src family member Yes and PI3K, leading to enhanced MMP expression. ${ }^{120}$ On first glance, CD95 and TRAIL appear to have similar mechanisms of non-canonical signaling, although this remains to be further examined. Overall, a picture emerges in which both non-apoptotic and apoptotic signaling by death receptors is important for their physiological functions.

\section{Concluding Remarks}

In pursue of novel potent tumor-selective apoptosis-inducing strategies, the TRAIL receptors provide excellent targets on first sight. Indeed, their favorable property of triggering tumorselective apoptosis has been demonstrated in many preclinical studies. However, it is becoming clear that signaling via the TRAIL receptors is much more complex than initially thought and can have different functional outcomes as is illustrated here. TRAIL receptor activation can have antitumor effects by inducing caspase-dependent apoptosis in TRAILsensitive cells, whereas in TRAIL-resistant tumor cells, the activation can lead to protumorigenic effects, such as enhanced proliferation, survival and invasion. Whether TRAIL-induced necroptosis contributes to antitumor activity remains to be demonstrated. The effects of TRAIL receptor activation in resistant tumor cells resemble that observed in non-transformed apoptosis-resistant (normal) cells. This suggests that the protumorigenic mechanisms elicited by TRAIL in resistant tumor cells are actually part of normal physiological signaling in non-transformed cells. However, an important difference is that combination therapies that sensitize cancer cells for TRAIL-induced apoptosis are in most cases not harmful for normal cells, indicating specific changes in tumor cells that allow the activation of caspasedependent apoptosis.

The precise kinase cascades triggered by TRAIL remain to be further identified, which is complicated due to crossactivation between kinases, cell type-dependent variation and effects of external stimuli produced by the tumor microenvironment. A number of studies have attempted to unravel the molecular mechanisms responsible for the dichotomy in 
TRAIL signaling, but the underlying mechanisms remain poorly understood. Thus far, the DISC (FADD, caspase-8) and the signaling complex (FADD, caspase-8, RIP1, TRAF2 and NEMO) have been identified ${ }^{27}$ as main mediators of apoptosis and non-apoptotic signals, respectively. RIP1dependent signaling can stimulate cell survival and even tumor cell invasion. In addition, TRAIL has been shown to induce RIP1-dependent necroptosis under specific conditions. The more precise mechanisms by which RIP1 can transmit these signals remain to be determined. Clearly, more research is required to unravel the molecular mechanism regulating non-canonical TRAIL signaling and to identify molecular switches that may be used for setting the system into the 'apoptosis position'. This will provide new clues for developing better strategies to use TRAIL receptor agonists for the treatment of cancer.

\section{Conflict of Interest}

The authors declare no conflict of interest.

Acknowledgements. This work was performed within the framework of the project T3-112 of the Dutch Top Institute Pharma, and supported by grant RUG2011-5211 from the Dutch Cancer Society. We thank Esther van Straten for making the figures.

1. Ashkenazi A. Directing cancer cells to self-destruct with pro-apoptotic receptor agonists. Nat Rev Drug Discov 2008; 7: 1001-1012.

2. Pitti RM, Marsters SA, Ruppert S, Donahue CJ, Moore A, Ashkenazi A. Induction of apoptosis by Apo-2 ligand, a new member of the tumor necrosis factor cytokine family. J Biol Chem 1996; 271: 12687-12690.

3. Wiley SR, Schooley K, Smolak PJ, Din WS, Huang CP, Nicholl JK et al. Identification and characterization of a new member of the TNF family that induces apoptosis. Immunity 1995; 3: 673-682.

4. Fulda S, Debatin KM. Exploiting death receptor signaling pathways for tumor therapy. Biochim Biophys Acta 2004; 1705: 27-41.

5. LeBlanc HN, Ashkenazi A. Apo2L/TRAIL and its death and decoy receptors. Cell Death Differ 2003; 10: 66-75.

6. Merino D, Lalaoui N, Morizot A, Schneider P, Solary E, Micheau O. Differential inhibition of TRAIL-mediated DR5-DISC formation by decoy receptors 1 and 2. Mol Cell Biol 2006; 26: 7046-7055.

7. Adams C, Totpal K, Lawrence D, Marsters S, Pitti R, Yee S et al. Structural and functional analysis of the interaction between the agonistic monoclonal antibody Apomab and the proapoptotic receptor DR5. Cell Death Differ 2008; 15: 751-761.

8. Ashkenazi A, Pai RC, Fong S, Leung S, Lawrence DA, Marsters SA et al. Safety and antitumor activity of recombinant soluble Apo2 ligand. J Clin Invest 1999; 104: 155-162.

9. van der Sloot AM, Tur V, Szegezdi E, Mullally MM, Cool RH, Samali A et al. Designed tumor necrosis factor-related apoptosis-inducing ligand variants initiating apoptosis exclusively via the DR5 receptor. Proc Natl Acad Sci USA 2006; 103: 8634-8639.

10. Walczak H, Miller RE, Ariail K, Gliniak B, Griffith TS, Kubin M et al. Tumoricidal activity of tumor necrosis factor-related apoptosis-inducing ligand in vivo. Nat Med 1999; 5: 157-163.

11. Lemke J, Noack A, Adam D, Tchikov V, Bertsch U, Roder $C$ et al. TRAIL signaling is mediated by DR4 in pancreatic tumor cells despite the expression of functional DR5. $J$ Mol Med (Berl) 2010; 88: 729-740.

12. MacFarlane M, Inoue S, Kohlhaas SL, Majid A, Harper N, Kennedy DB et al. Chronic lymphocytic leukemic cells exhibit apoptotic signaling via TRAIL-R1. Cell Death Differ 2005; 12: 773-782.

13. Bellail AC, Tse MC, Song JH, Phuphanich S, Olson JJ, Sun SY et al. DR5-mediated DISC controls caspase-8 cleavage and initiation of apoptosis in human glioblastomas. J Cell Mol Med 2010; 14: 1303-1317.

14. Kelley RF, Totpal K, Lindstrom SH, Mathieu M, Billeci K, Deforge L et al. Receptorselective mutants of apoptosis-inducing ligand 2/tumor necrosis factor-related apoptosisinducing ligand reveal a greater contribution of death receptor (DR) 5 than DR4 to apoptosis signaling. J Biol Chem 2005; 280: 2205-2212.

15. Pennarun B, Meijer A, de Vries EG, Kleibeuker JH, Kruyt F, de Jong S. Playing the DISC: turning on TRAIL death receptor-mediated apoptosis in cancer. Biochim Biophys Acta 2010; 1805: 123-140.

16. Ozoren N, El-Deiry WS. Defining characteristics of types I and II apoptotic cells in response to TRAIL. Neoplasia 2002; 4: 551-557.
17. Du C, Fang M, Li Y, Li L, Wang X. Smac, a mitochondrial protein that promotes cytochrome c-dependent caspase activation by eliminating IAP inhibition. Cell 2000; 102 : 33-42.

18. Vanlangenakker N, Vanden Berghe $T$, Vandenabeele $P$. Many stimuli pull the necrotic trigger, an overview. Cell Death Differ 2012; 19: 75-86.

19. Jouan-Lanhouet S, Arshad MI, Piquet-Pellorce C, Martin-Chouly C, Le Moigne-Muller G, Van HF et al. TRAIL induces necroptosis involving RIPK1/RIPK3-dependent PARP-1 activation. Cell Death Differ 2012; 19: 2003-2014.

20. Falschlehner $\mathrm{C}$, Emmerich $\mathrm{CH}$, Gerlach $\mathrm{B}$, Walczak $\mathrm{H}$. TRAIL signaling: decisions between life and death. Int. J Biochem Cell Biol 2007; 39: 1462-1475.

21. Stegehuis JH, de Wilt LH, de Vries EG, Groen HJ, de Jong S, Kruyt FA. TRAIL receptor targeting therapies for non-small cell lung cancer: current status and perspectives. Drug Resist Updat 2010; 13: 2-15.

22. Hellwig CT, Rehm M. TRAIL signaling and synergy mechanisms used in TRAIL-based combination therapies. Mol Cancer Ther 2012; 11: 3-13.

23. Hotte SJ, Hirte HW, Chen EX, Siu LL, Le LH, Corey A et al. A phase 1 study of mapatumumab (fully human monoclonal antibody to TRAIL-R1) in patients with advanced solid malignancies. Clin Cancer Res 2008; 14: 3450-3455.

24. Merchant MS, Geller JI, Baird K, Chou AJ, Galli S, Charles A et al. Phase I trial and pharmacokinetic study of lexatumumab in pediatric patients with solid tumors. J Clin Oncol 2012; 30: 4141-4147.

25. Soria JC, Smit E, Khayat D, Besse B, Yang X, Hsu CP et al. Phase $1 \mathrm{~b}$ study of dulanermin (recombinant human Apo2L/TRAIL) in combination with paclitaxel, carboplatin, and bevacizumab in patients with advanced non-squamous non-small-cell lung cancer. $J$ Clin Oncol 2010; 28: 1527-1533.

26. Tolcher AW, Mita M, Meropol NJ, von MM, Patnaik A, Padavic K et al. Phase I pharmacokinetic and biologic correlative study of mapatumumab, a fully human monoclonal antibody with agonist activity to tumor necrosis factor-related apoptosisinducing ligand receptor-1. J Clin Oncol 2007; 25: 1390-1395.

27. Varfolomeev E, Maecker H, Sharp D, Lawrence D, Renz M, Vucic D et al. Molecular determinants of kinase pathway activation by Apo2 ligand/tumor necrosis factor-related apoptosis-inducing ligand. J Biol Chem 2005; 280: 40599-40608.

28. Song JH, Tse MC, Bellail A, Phuphanich S, Khuri F, Kneteman NM et al. Lipid rafts and nonrafts mediate tumor necrosis factor related apoptosis-inducing ligand induced apoptotic and nonapoptotic signals in non small cell lung carcinoma cells. Cancer Res 2007; 67: 6946-6955.

29. Ouyang W, Yang C, Liu Y, Xiong J, Zhang J, Zhong Y et al. Redistribution of DR4 and DR5 in lipid rafts accounts for the sensitivity to TRAIL in NSCLC cells. Int. J Oncol 2011; 39: 1577-1586.

30. Vucic D, Dixit VM, Wertz IE. Ubiquitylation in apoptosis: a post-translational modification at the edge of life and death. Nat Rev Mol Cell Biol 2011; 12: 439-452.

31. Wilson NS, Dixit V, Ashkenazi A. Death receptor signal transducers: nodes of coordination in immune signaling networks. Nat Immunol 2009; 10: 348-355.

32. Chaudhary PM, Eby M, Jasmin A, Bookwalter A, Murray J, Hood L. Death receptor 5, a new member of the TNFR family, and DR4 induce FADD-dependent apoptosis and activate the NF-kappaB pathway. Immunity 1997; 7: 821-830.

33. Schneider P, Thome M, Burns K, Bodmer JL, Hofmann K, Kataoka T et al. TRAIL receptors 1 (DR4) and 2 (DR5) signal FADD-dependent apoptosis and activate NF-kappaB. Immunity 1997; 7 : 831-836.

34. Sheridan JP, Marsters SA, Pitti RM, Gurney A, Skubatch M, Baldwin D et al. Control of TRAIL-induced apoptosis by a family of signaling and decoy receptors. Science 1997; 277: 818-821.

35. Henson ES, Gibson EM, Villanueva J, Bristow NA, Haney N, Gibson SB. Increased expression of Mcl-1 is responsible for the blockage of TRAIL-induced apoptosis mediated by EGF/ErbB1 signaling pathway. J Cell Biochem 2003; 89: 1177-1192.

36. Kreuz S, Siegmund D, Scheurich P, Wajant H. NF-kappaB inducers upregulate cFLIP, a cycloheximide-sensitive inhibitor of death receptor signaling. Mol Cell Biol 2001; 21: 3964-3973.

37. Mitsiades N, Mitsiades CS, Poulaki V, Chauhan D, Richardson PG, Hideshima T et al. Biologic sequelae of nuclear factor-kappaB blockade in multiple myeloma: therapeutic applications. Blood 2002; 99: 4079-4086.

38. Ravi R, Bedi GC, Engstrom LW, Zeng Q, Mookerjee B, Gelinas C et al. Regulation of death receptor expression and TRAIL/Apo2L-induced apoptosis by NF-kappaB. Nat. Cell Biol 2001; 3: 409-416.

39. Ehrhardt H, Fulda S, Schmid I, Hiscott J, Debatin KM, Jeremias I. TRAIL induced survival and proliferation in cancer cells resistant towards TRAIL-induced apoptosis mediated by NF-kappaB. Oncogene 2003; 22: 3842-3852.

40. Karacay B, Sanlioglu S, Griffith TS, Sandler A, Bonthius DJ. Inhibition of the NF-kappaB pathway enhances TRAIL-mediated apoptosis in neuroblastoma cells. Cancer Gene Ther 2004; 11: 681-690.

41. Braeuer SJ, Buneker C, Mohr A, Zwacka RM. Constitutively activated nuclear factorkappaB, but not induced NF-kappaB, leads to TRAIL resistance by up-regulation of X-linked inhibitor of apoptosis protein in human cancer cells. Mol Cancer Res 2006; 4 : 715-728.

42. Roue G, Perez-Galan P, Lopez-Guerra M, Villamor N, Campo E, Colomer D. Selective inhibition of IkappaB kinase sensitizes mantle cell lymphoma $B$ cells to TRAIL by decreasing cellular FLIP level. J Immunol 2007; 178: 1923-1930. 
43. Voortman J, Resende TP, Abou El Hassan MA, Giaccone G, Kruyt FA. TRAIL therapy in non-small cell lung cancer cells: sensitization to death receptor-mediated apoptosis by proteasome inhibitor bortezomib. Mol Cancer Ther 2007; 6: 2103-2112.

44. Jennewein C, Karl S, Baumann B, Micheau O, Debatin KM, Fulda S. Identification of a novel pro-apoptotic role of NF-kappaB in the regulation of T. Oncogene 2012; 31: 1468-1474.

45. Chang L, Karin M. Mammalian MAP kinase signaling cascades. Nature 2001; 410: 37-40.

46. Muhlenbeck F, Haas E, Schwenzer R, Schubert G, Grell M, Smith C et al. TRAIL/Apo2L activates c-Jun NH2-terminal kinase (JNK) via caspase-dependent and caspaseindependent pathways. J Biol Chem 1998; 273: 33091-33098

47. Herr I, Wilhelm D, Meyer E, Jeremias I, Angel P, Debatin KM. JNK/SAPK activity contributes to TRAIL-induced apoptosis. Cell Death Differ 1999; 6: 130-135.

48. Hu WH, Johnson H, Shu HB. Tumor necrosis factor-related apoptosis-inducing ligand receptors signal NF-kappaB and JNK activation and apoptosis through distinct pathways. J Biol Chem 1999; 274: 30603-30610.

49. Lin Y, Devin A, Cook A, Keane MM, Kelliher M, Lipkowitz S et al. The death domain kinase RIP is essential for TRAIL (Apo2L)-induced activation of IkappaB kinase and c-Jun N-terminal kinase. Mol Cell Biol 2000; 20: 6638-6645.

50. Corazza N, Jakob S, Schaer C, Frese S, Keogh A, Stroka D et al. TRAIL receptormediated JNK activation and Bim phosphorylation critically regulate Fas-mediated live damage and lethality. J Clin Invest 2006; 116: 2493-2499.

51. Werneburg NW, Guicciardi ME, Bronk SF, Kaufmann SH, Gores GJ. Tumor necrosis factor-related apoptosis-inducing ligand activates a lysosomal pathway of apoptosis that is regulated by Bcl-2 proteins. J Biol Chem 2007; 282: 28960-28970.

52. Park KJ, Lee SH, Lee CH, Jang JY, Chung J, Kwon MH et al. Upregulation of Beclin-1 expression and phosphorylation of $\mathrm{Bcl}-2$ and $\mathrm{p} 53$ are involved in the JNK-mediated autophagic cell death. Biochem Biophys Res Commun 2009; 382: 726-729.

53. Ohtsuka T, Buchsbaum D, Oliver P, Makhija S, Kimberly R, Zhou T. Synergistic induction of tumor cell apoptosis by death receptor antibody and chemotherapy agent through JNK p38 and mitochondrial death pathway. Oncogene 2003; 22: 2034-2044

54. Mucha SR, Rizzani A, Gerbes AL, Camaj P, Thasler WE, Bruns CJ et al. JNK inhibition sensitises hepatocellular carcinoma cells but not normal hepatocytes to the TNF-related apoptosis-inducing ligand. Gut 2009; 58: 688-698.

55. Ventura JJ, Hubner A, Zhang C, Flavell RA, Shokat KM, Davis RJ. Chemical genetic analysis of the time course of signal transduction by JNK. Mol Cell 2006; 21: 701-710.

56. Mahalingam D, Keane M, Pirianov G, Mehmet $H$, Samali A, Szegezdi E. Differentia activation of JNK1 isoforms by TRAIL receptors modulate apoptosis of colon cancer cell lines. Br J Cancer 2009; 100: 1415-1424.

57. Lee MW, Park SC, Yang YG, Yim SO, Chae HS, Bach JH et al. The involvement of reactive oxygen species (ROS) and p38 mitogen-activated protein (MAP) kinase in TRAIL/Apo2L-induced apoptosis. FEBS Lett 2002; 512: 313-318.

58. Zhang L, Zhu H, Davis JJ, Jacob D, Wu S, Teraishi F et al. Lack of p38 MAP kinase activation in TRAIL-resistant cells is not related to the resistance to TRAIL-mediated cell death. Cancer Biol Ther 2004; 3: 296-301.

59. Son JK, Varadarajan S, Bratton SB. TRAIL-activated stress kinases suppress apoptosis through transcriptional upregulation of MCL-1. Cell Death Differ 2010; 17: 1288-1301.

60. Weldon CB, Parker AP, Patten D, Elliott S, Tang Y, Frigo DE et al. Sensitization of apoptotically-resistant breast carcinoma cells to TNF and TRAIL by inhibition of p38 mitogen-activated protein kinase signaling. Int J Oncol 2004; 24: 1473-1480.

61. Milani D, Zauli G, Rimondi E, Celeghini C, Marmiroli S, Narducci P et al. Tumour necrosis factor-related apoptosis-inducing ligand sequentially activates pro-survival and proapoptotic pathways in SK-N-MC neuronal cells. J Neurochem 2003; 86: 126-135.

62. Vaculova A, Hofmanova J, Soucek K, Kozubik A. Different modulation of TRAlL-induced apoptosis by inhibition of pro-survival pathways in TRAIL-sensitive and TRAIL-resistan colon cancer cells. FEBS Lett 2006; 580: 6565-6569.

63. Belyanskaya LL, Ziogas A, Hopkins-Donaldson S, Kurtz S, Simon HU, Stahel R et al. TRAIL-induced survival and proliferation of SCLC cells is mediated by ERK and dependent on TRAIL-R2/DR5 expression in the absence of caspase-8. Lung Cancer 2008; 60: 355-365

64. Zhang XD, Borrow JM, Zhang XY, Nguyen T, Hersey P. Activation of ERK1/2 protects melanoma cells from TRAIL-induced apoptosis by inhibiting Smac/DIABLO release from mitochondria. Oncogene 2003; 22: 2869-2881.

65. Vilimanovich $U$, Bumbasirevic V. TRAIL induces proliferation of human glioma cells by c-FLIPL-mediated activation of ERK1/2. Cell Mol Life Sci 2008; 65: 814-826.

66. Song JJ, Lee YJ. Differential cleavage of Mst1 by caspase-7/-3 is responsible for TRAILinduced activation of the MAPK superfamily. Cell Signal 2008; 20: 892-906.

67. Sun BK, Kim JH, Nguyen HN, Kim SY, Oh S, Lee YJ et al. TRAlL-induced caspase/p38 activation is responsible for the increased catalytic and invasive activities of Akt. Int $J$ Oncol 2011; 38: 249-256

68. Choo MK, Kawasaki N, Singhirunnusorn P, Koizumi K, Sato S, Akira S et al. Blockade of transforming growth factor-beta-activated kinase 1 activity enhances TRAIL-induced apoptosis through activation of a caspase cascade. Mol. Cancer Ther 2006; 5 2970-2976.

69. Morioka S, Omori E, Kajino T, Kajino-Sakamoto R, Matsumoto K, Ninomiya-Tsuji J. TAK1 kinase determines TRAIL sensitivity by modulating reactive oxygen species and cIAP. Oncogene 2009; 28: 2257-2265.
70. Trauzold A, Wermann H, Arlt A, Schutze S, Schafer H, Oestern S et al. CD95 and TRAIL receptor-mediated activation of protein kinase $\mathrm{C}$ and NF-kappaB contributes to apoptosis resistance in ductal pancreatic adenocarcinoma cells. Oncogene 2001; 20: 4258-4269.

71. Gillespie $S$, Zhang $X D$, Hersey $P$. Variable expression of protein kinase $C$ epsilon in human melanoma cells regulates sensitivity to TRAIL-induced apoptosis. $\mathrm{Mol}$ Cancer Ther 2005; 4: 668-676.

72. Shankar E, Sivaprasad U, Basu A. Protein kinase C epsilon confers resistance of MCF-7 cells to TRAIL by Akt-dependent activation of $\mathrm{Hdm} 2$ and downregulation of p53. Oncogene 2008; 27: 3957-3966.

73. Harper N, Hughes MA, Farrow SN, Cohen GM, MacFarlane M. Protein kinase C modulates tumor necrosis factor-related apoptosis-inducing ligand-induced apoptosis by targeting the apical events of death receptor signaling. J Biol Chem 2003; 278: $44338-44347$.

74. Farrow B, Thomas RP, Wang XF, Evers BM. Activation of conventional PKC isoforms increases expression of the pro-apoptotic protein Bad and TRAIL receptors. Int $J$ Gastrointest Cancer 2002; 32: 63-72.

75. Chen W, Wang X, Zhuang J, Zhang L, Lin Y. Induction of death receptor 5 and suppression of survivin contribute to sensitization of TRAlL-induced cytotoxicity by quercetin in non-small cell lung cancer cells. Carcinogenesis 2007; 28: 2114-2121.

76. Fresno Vara JA, Casado E, de Castro J, Cejas P, Belda-Iniesta C, Gonzalez-Baron M. PI3K/Akt signaling pathway and cancer. Cancer Treat Rev 2004; 30: 193-204.

77. Zauli G, Sancilio S, Cataldi A, Sabatini N, Bosco D, Di PR. PI-3K/Akt and NF-kappaB/ Ikappa Balpha pathways are activated in Jurkat T cells in response to TRAIL treatment. $J$ Cell Physiol 2005; 202: 900-911.

78. Ozes ON, Mayo LD, Gustin JA, Pfeffer SR, Pfeffer LM, Donner DB. NF-kappaB activation by tumour necrosis factor requires the Akt serine-threonine kinase. Nature 1999; 401: 82-85.

79. Wang D, Baldwin AS Jr. Activation of nuclear factor-kappaB-dependent transcription by tumor necrosis factor-alpha is mediated through phosphorylation of RelA/p65 on serine 529. J Biol Chem 1998; 273: 29411-29416.

80. Tanaka H, Fujita N, Tsuruo T. 3-Phosphoinositide-dependent protein kinase-1-mediated IkappaB kinase beta (IkkB) phosphorylation activates NF-kappaB signaling. J Biol Chem 2005; 280: 40965-40973

81. Xu J, Zhou JY, Wei WZ, Wu GS. Activation of the Akt survival pathway contributes to TRAIL resistance in cancer cells. PLOS One 2010; 5: e10226.

82. Azijli K, Yuvaraj S, Peppelenbosch MP, Wurdinger T, Dekker H, Joore J et al. Kinome profiling of non-canonical TRAIL signaling reveals RIP1-Src-STAT3 dependent invasion in resistant non-small cell lung cancer cells. J Cell Sci 2012; 125: 4651-4661.

83. Song JJ, Kim JH, Sun BK, Alcala MA Jr., Bartlett DL, Lee YJ. c-Cbl acts as a mediator of Src-induced activation of the PI3K-Akt signal transduction pathway during TRAIL treatment. Cell Signal 2010; 22: 377-385.

84. Song JJ, An JY, Kwon YT, Lee YJ. Evidence for two modes of development of acquired tumor necrosis factor-related apoptosis-inducing ligand resistance. Involvement of $\mathrm{Bcl}-\mathrm{XL}$. J Biol Chem 2007; 282: 319-328.

85. Lalaoui N, Morle A, Merino D, Jacquemin G, lessi E, Morizot A et al. TRAIL-R4 promotes tumor growth and resistance to apoptosis in cervical carcinoma HeLa cells through AKT. PLoS One 2011; 6: e19679.

86. De Toni EN, Kuntzen C, Gerbes AL, Thasler WE, Sonuc N, Mucha SR et al. P60-c-src suppresses apoptosis through inhibition of caspase 8 activation in hepatoma cells, but not in primary hepatocytes. $J$ Hepatol 2007; 46: 682-691.

87. Zhang $X H$, Wang Q, Gerald W, Hudis CA, Norton L, Smid M et al. Latent bone metastasis in breast cancer tied to Src-dependent survival signals. Cancer Cell 2009; 16: 67-78.

88. Cursi S, Rufini A, Stagni V, Condo I, Matafora V, Bachi A et al. Src kinase phosphorylates Caspase-8 on Tyr380: a novel mechanism of apoptosis suppression. EMBO J 2006; 25: 1895-1905.

89. Van Schaeybroeck S, Kelly DM, Kyula J, Stokesberry S, Fennell DA, Johnston PG et al. Src and ADAM-17-mediated shedding of transforming growth factor-alpha is a mechanism of acute resistance to TRAIL. Cancer Res 2008; 68: 8312-8321.

90. Cretney E, Takeda K, Yagita H, Glaccum M, Peschon JJ, Smyth MJ. Increased susceptibility to tumor initiation and metastasis in TNF-related apoptosis-inducing liganddeficient mice. J Immunol 2002; 168: 1356-1361.

91. Grosse-Wilde A, Voloshanenko O, Bailey SL, Longton GM, Schaefer U, Csernok Al et al. TRAIL-R deficiency in mice enhances lymph node metastasis without affecting primary tumor development. J Clin Invest 2008; 118: 100-110.

92. Ishimura N, Isomoto H, Bronk SF, Gores GJ. Trail induces cell migration and invasion in apoptosis-resistant cholangiocarcinoma cells. Am J Physiol Gastrointest Liver Physiol 2006; 290: G129-G136.

93. Trauzold A, Siegmund D, Schniewind B, Sipos B, Egberts J, Zorenkov D et al. TRAlL promotes metastasis of human pancreatic ductal adenocarcinoma. Oncogene 2006; 25: 7434-7439.

94. Zhou DH, Trauzold A, Roder C, Pan G, Zheng C, Kalthoff $H$. The potential molecular mechanism of overexpression of UPA, IL-8, MMP-7 and MMP-9 induced by TRAIL in pancreatic cancer cell. Hepatobiliary Pancreat Dis Int 2008; 7: 201-209.

95. Ehrenschwender M, Siegmund D, Wicovsky A, Kracht M, ttrich-Breiholz O, Spindler V et al. Mutant PIK3CA licenses TRAIL and CD95L to induce non-apoptotic caspase-8mediated ROCK activation. Cell Death Differ 2010; 17: 1435-1447. 
96. Hoogwater FJ, Nijkamp MW, Smakman N, Steller EJ, Emmink BL, Westendorp BF et al. Oncogenic K-Ras turns death receptors into metastasis-promoting receptors in human and mouse colorectal cancer cells. Gastroenterology 2010; 138: 2357-2367.

97. Gonzalvez F, Ashkenazi A. New insights into apoptosis signaling by Apo2L/TRAIL. Oncogene 2010; 29: 4752-4765.

98. Secchiero P, Gonelli A, Carnevale E, Milani D, Pandolfi A, Zella D et al. TRAIL promotes the survival and proliferation of primary human vascular endothelial cells by activating the Akt and ERK pathways. Circulation 2003; 107: 2250-2256.

99. Li JH, Kirkiles-Smith NC, McNiff JM, Pober JS. TRAIL induces apoptosis and inflammatory gene expression in human endothelial cells. J Immunol 2003; 171: $1526-1533$.

100. Secchiero P, Corallini F, di lasio MG, Gonelli A, Barbarotto E, Zauli G. TRAIL counteracts the proadhesive activity of inflammatory cytokines in endothelial cells by down-modulating CCL8 and CXCL10 chemokine expression and release. Blood 2005; 105: 3413-3419.

101. Wilson NS, Yang A, Yang B, Couto S, Stern H, Gogineni A et al. Proapoptotic activation of death receptor 5 on tumor endothelial cells disrupts the vasculature and reduces tumor growth. Cancer Cell 2012; 22: 80-90.

102. Secchiero P, Zerbinati C, Rimondi E, Corallini F, Milani D, Grill V et al. TRAIL promotes the survival, migration and proliferation of vascular smooth muscle cells. Cell Mol Life Sci 2004; 61: 1965-1974.

103. Kavurma MM, Schoppet M, Bobryshev YV, Khachigian LM, Bennett MR. TRAIL stimulates proliferation of vascular smooth muscle cells via activation of NF-kappaB and induction of insulin-like growth factor-1 receptor. J Biol Chem 2008; 283 : 7754-7762.

104. Chan J, Prado-Lourenco L, Khachigian LM, Bennett MR, Di Bartolo BA, Kavurma MM TRAIL promotes VSMC proliferation and neointima formation in a FGF-2-, Sp1 phosphorylation-, and NFkappaB-dependent manner. Circ Res 2010; 106: 1061-1071.

105. Chou AH, Tsai HF, Lin LL, Hsieh SL, Hsu PI, Hsu PN. Enhanced proliferation and increased IFN-gamma production in T cells by signal transduced through TNF-related apoptosis-inducing ligand. J Immunol 2001; 167: 1347-1352.

106. Robertson NM, Zangrilli JG, Steplewski A, Hastie A, Lindemeyer RG, Planeta MA et al. Differential expression of TRAIL and TRAIL receptors in allergic asthmatics following segmental antigen challenge: evidence for a role of TRAIL in eosinophil survival. $\mathrm{J}$ Immunol 2002; 169: 5986-5996.

107. Morel J, Audo R, Hahne M, Combe B. Tumor necrosis factor-related apoptosis-inducing ligand (TRAIL) induces rheumatoid arthritis synovial fibroblast proliferation through mitogen-activated protein kinases and phosphatidylinositol 3-kinase/Akt. J Biol Chem 2005; 280: 15709-15718.

108. Rimondi E, Secchiero P, Quaroni A, Zerbinati C, Capitani S, Zauli G. Involvement of TRAIL/TRAIL-receptors in human intestinal cell differentiation. J Cell Physiol 2006; 206 647-654.

109. Wu NL, Lee TA, Tsai TL, Lin WW. TRAIL-induced keratinocyte differentiation requires caspase activation and p63 expression. J Invest Dermatol 2011; 131: 874-883.

110. Yen ML, Tsai HF, Wu YY, Hwa HL, Lee BH, Hsu PN. TNF-related apoptosis-inducing ligand (TRAIL) induces osteoclast differentiation from monocyte/macrophage lineage precursor cells. Mol Immunol 2008; 45: 2205-2213.

111. Kim JY, Lee JY, Kim DG, Koo GB, Yu JW, Kim YS. TRADD is critical for resistance to TRAIL-induced cell death through NF-kappaB activation. FEBS Lett 2011; 585: 2144-2150.

112. Lluis JM, Nachbur U, Cook WD, Gentle IE, Moujalled D, Moulin M et al. TAK1 is required for survival of mouse fibroblasts treated with TRAIL, and does so by NF-kappaB dependent induction of CFLIPL. PLoS One 2010; 5: e8620.

113. Cao X, Pobezinskaya YL, Morgan MJ, Liu ZG. The role of TRADD in TRAIL-induced apoptosis and signaling. FASEB J 2011; 25: 1353-1358.

114. Peter ME, Budd RC, Desbarats J, Hedrick SM, Hueber AO, Newell MK et al. The CD95 receptor: apoptosis revisited. Cell 2007; 129: 447-450.

115. Desbarats J, Newell MK. Fas engagement accelerates liver regeneration after partial hepatectomy. Nat Med 2000; 6: 920-923.

116. Tamm C, Robertson JD, Sleeper E, Enoksson M, Emgard M, Orrenius S et al. Differential regulation of the mitochondrial and death receptor pathways in neural stem cells. Eur $J$ Neurosci 2004; 19: 2613-2621.

117. Zuliani C, Kleber S, Klussmann S, Wenger T, Kenzelmann M, Schreglmann $\mathrm{N}$ et al. Control of neuronal branching by the death receptor CD95 (Fas/Apo-1). Cell Death Differ 2006; 13: 31-40.

118. Lee JK, Sayers TJ, Back TC, Wigginton JM, Wiltrout RH. Lack of FasL-mediated killing leads to in vivo tumor promotion in mouse Lewis lung cancer. Apoptosis 2003; 8: 151-160.

119. Barnhart BC, Legembre P, Pietras E, Bubici C, Franzoso G, Peter ME. CD95 ligand induces motility and invasiveness of apoptosis-resistant tumor cells. EMBO J 2004; 23 3175-3185.

120. Kleber S, Sancho-Martinez I, Wiestler B, Beisel A, Gieffers C, Hill O et al. Yes and PI3K bind CD95 to signal invasion of glioblastoma. Cancer Cell 2008; 13: 235-248. 